SOSIOLIUM

\title{
PENANAMAN NILAI KARAKTER DAN MULTIKULTURAL DALAM PEMBELAJARAN ILMU PENGETAHUAN SOSIAL DI SMP NEGERI 2 BLORA
}

\author{
Arya Sena Nugraha, Rudi Salam ${ }^{\bowtie}$ \\ Prodi Pendidikan IPS, Fakultas Ilmu Sosial, Universitas Negeri Semarang, Indonesia
}

\begin{abstract}
Info Artikel
Sejarah Artikel:

Disubmit: Juli 2021

Direvisi: Agustus 2021

Diterima: September 2021

Keywords:

Social Science Learning,

Character Education,

Multicultural Education.

Abstrak

SMP Negeri 2 Blora adalah sekolah dengan keberagaman siswa dan guru di dalam sekolah, mulai dari budaya, bahsa, agama, status sosial, gender, kemampuan, umur dan ras. Tujuan penelitian ini untuk mengetahui cara menanamkan nilai karakter dan multikultural dalam pemelajaran IPS dan faktor penunjang penanaman nilai karakter dan multikultural di SMP Negeri 2 Blora. Jenis penelitian ini adalah penelitian kualitatif. Hasil penelitian ini menunjukkan bahwa penanaman nilai karakter dan multikultural dapat diterapkan dalam pembelajaran IPS dengan pengintegrasian materi-materi yang mengandung muatan nilai karakter dan nilai multikultural di dalamnya. Penanaman nilai karakter dan multikultural dalam pembelajaran ilmu pengetahuan sosial di SMP Negeri 2 Blora melalui kegiatan belajar mengajar seperti kerja kelompok, memanfaatkan lingkungan sebagai sumber belajar dan penggunaan metode ceramah. Nilai karakter yang ditanamkan dalam pembelajaran IPS diambil dari nilai utama dalam program Gerakan PPK dan untuk nilai multikultural berpedoman langung pada nilai toleransi, kesamaan/ kesetaraan, kekerabatan/ persaudaraan, persatuan dan keadilan. Penanaman nilai karakter dan multikultural didukung dengan adanya faktor penunjang dalam penanaman, yakni dilaksanakan dalam proses pembelajaran di lingkungan sekolah yang berkaitan secara langsung dengan peserta didik.
\end{abstract}

\begin{abstract}
Junior High School 2 Blora is a school with a diversity of students and teachers in the school, ranging from culture, language, religion, social status, gender, ability, age and race. The purpose of this study was to find out how to instill character and multicultural values in social studies learning and the supporting factors for inculcating character and multicultural values in JHS 2 Blora. This type of research is qualitative research. The results of this study indicate that the cultivation of character and multicultural values can be applied in social studies learning by integrating materials that contain character values and multicultural values in them. Instilling character and multicultural values in social science learning at JHS 2 Blora through teaching and learning activities such as group work, utilizing the environment as a learning resource and using the lecture method. The character values inculcated in social studies learning are taken from the main values in the PPK Movement program and for multicultural values it is directly guided by the values of tolerance, equality/equality, kinship/brotherhood, unity and justice. The cultivation of character and multicultural values is supported by the existence of supporting factors in planting, which is carried out in the learning process in the school environment that is directly related to students.
\end{abstract}

(C) 2021 Universitas Negeri Semarang

\footnotetext{
Alamat korespondensi:

Gedung C1 Lantai 1 FIS Unnes

Kampus Sekaran, Gunungpati, Semarang, 50229
}

E-ISSN 2685-4929

E-mail: rudisalam@mail.unnes.ac.id 


\section{PENDAHULUAN}

Pendidikan merupakan bagian dari kegiatan kehidupan bermasyarakat, berbangsa, dan negara. Pelaksanaan kegiatan pendidikan merupakan perwujudan dari cita-cita bangsa. Kegiatan pendidikan nasional perlu diorganisasikan dan dikelola sedemikian rupa agar pendidikan nasional dalam pandangan masyarakat dianggap sebagai suatu organisasi dapat menjadi sarana untuk mewujudkan citacita nasional yang mengandung nilai-nilai semangat multikultural.

Crandall dalam Elma (2018) mengungkapkan bahwa pendidikan multikultural merupakan pendidikan yang memfokuskan pada latar belakang siswa baik dari aspek ras, keagamaan suku (etnis), budaya (kultur) dan agama. Hal ini mengandung pemahaman bahwa perbedaan yang ada bukan menjadi alasan untuk memberikan perlakuan yang berbeda kepada masing-masing peserta didik. Pembentukan karakter pada siswa tidak hanya bertujuan supaya siswa mudah memahami pelajaran yang dipelajarinya, akan tetapi juga untuk meningkatkan kesadaran mereka agar selalu berperilaku humanis, pluralis dan demokratis.

Praktek pendidikan multikultural di Indonesia dilaksanakan dalam pendidikan formal, informal maupun non formal. Salah satu yang menjadi topik pembicaraan hangat adalah pada pelaksanaan pendidikan formal. Secara fleksibel, tidak harus berupa mata pelajaran yang terpisah, namun yang sudah terjadi adalah terimplementasinya nilai-nilai pendidikan multikultural yang berbasis penanaman karakter kepada peserta didik. Penyelenggaraan pendidikan multikultural diyakini menjadi solusi nyata konflik yang ada dalam masyarkat. Selain sebagai sarana alternatif pemecahan konflik, pendidikan multikultural juga signifikan dalam membentuk karakter siswa, agar tidak tercabut dari akar budaya yang dimilikinya, takkala ia berhadapan dengan realitas sosial budaya di era globalisasi yang terus berkembang. Maka penyelenggaran pendidikan multikultural dapat dikatakan berhasil jika dapat melahirkan peserta didik yang memiliki sikap hidup toleran, tidak bermusuhan, dan tidak berkonflik yang disebabkan oleh perbedaan budaya, suku, adat istiadat, klas sosial, kemampuan, dan lain-lain.

Zubaedi, (2012) menyatakan bahwa karakter adalah cara berfikir dan berperilaku yang menjadi ciri khas tiap individu untuk dan bekerja sama, baik dalam lingkungan keluarga, masyarakat, bangsa, dan negara. Karakter adalah potret diri seseorang yang sesungguhnya. Setiap orang memiliki karakter dan itu bisa menggambarkan diri seseorang yang sebenarnya apakah baik atau buruk.

Karakter siswa merupakan salah satu topik yang kini menjadi bahan pembiaraan di dalam dunia pendidikan. Banyak permasalahan mengenai terkikisnya karakter siswa yang melibatkan pelajar sekolah khususnya di tingkat SMP telah menjadi pemberitaan dan sorotan tajam masyarakat. Lemahnya karakter siswa sperti tawuran, bullying dan kekerassan pelajar dari tahun ke taun semakin meningkat. Jatidiri seorang pelajar seakan sudah hilang begitu saja, karena derasnya arus globalisasi. Nilai- nilai keramahan, kesoponana, rendah hati, dan gotong royong yang sudah dibangun masyarakat sudah jarang terlihat dari dalam diri siswa. Generasi muda Indonesia sendiri mulai meninggalkan budaya lokal dan beralih ke budaya barat sebagai contoh derasnya arus globalisasi.

Omeri, (2015) menjelaskan bahwa pendidikan karakter adalah suatu sistem penanaman nilai-nilai karakter yang meliputi komponen pengetahuan, kesadaran, dan tindakan untuk melaksanakan nilai-nilai tersebut, baik terhadap Tuhan Yang Maha Esa, diri sendiri, sesama, lingkungan, maupun lingkungan. Melalui pendidikan karakter diharapkan siswa secara utuh mampu secara mandiri meningkatkan dan menggunakan pengetahuanya, mengkaji dan menginternalisasikan serta mempersoanalisasi nilai karakter dan akhlak mulia tersebut sehingga terwujud dalam kehidupan sehari-hari. Pembentukan karakter siswa nantinya bepedoman padas 5 nilai utama karakter prioritas PPK dari kementrian pendidikan dan kebudayaan Indonesia. Program PPK (Penguatan Pendidikan Karakter) digagas oleh Kemdikbud sejalan dengan upaya menyukseskan Gerakan Nasional Revolusi Mental yang di gagas oleh Presiden Joko Widodo. Penguatan Pendidikan Karakter (PPK) merupakan amanat Nawa Cita yang dicanangkan Presiden. Nawa Cita tersebut tertuang pada butir ke depalan yaitu tentang mengadakan revolusi karakter.

Pembelajaran Pendidikan IPS di sekolahsekolah Indonesia, wacana toleransi dan kesadaran bahwa negara ini terdiri dari masyarakat yang beraneka ragam suku, agama, 
ras, dan golongan terus menerus didiktekan oleh guru kepada para murid. Namun, seringkali hal ini hanya diterapkan oleh guru BK saja dengan penggunaan strategi pengajaran lisan yang cenderung teoritik yang tidak cukup efektif. Dalam hal ini pendidikan multikultural dapat secara langsung juga membuntuk karakter siswa melalui PPK.

SMP Negeri 2 Blora merupakan salah satu sekolah menengah pertama di Kabupaten Blora yang menerapkan pendidikan multikutural dalam muatan pembelajaran dan menjadi sekolah tujuan untuk siswa yang beragama non islam seperti kristen, dan katolik. Hal ini menjadi dasar pentingnya penerapan pendidikan multikultural dan pembentukan karakter siswa di SMP Negeri 2 Blora, karena dari hasil observasi yang diperoleh dari wakil kepala sekolah bidang kurikulum dan akademik SMP Negeri 2 Blora terapat 948 siswa yang terdiri dari 315 siswa kelas VII, kelas VIII terdiri dari 318 siswa, dan kelas IX terdiri dari 315 siswa, terdiri dari 434 siswa bejenis kelamin laki-laki dan ada 514 siswa berjenis kelamin perempuan, serta 37 siswa yang beragama kristen dan 14 siswa yang beragama katholik, banyak siswa yang memiliki perbedaan dari agama, ras, dan budaya agar tidak terjadi sebuah konflik antar siswa yang didasarkan oleh agama, budaya, dan ras. Perbedaan dalam siswa di SMP Negeri 2 Blora di karenakan adanya orang tua siswa yang bekerja sebagai TNI-AD yang datang dari berbagai provinsi di Indonesia dan berdinas di Batalyon Infantri 410, hal ini mendorong para siswa yang berasal dari luar jawa untuk bersekolah di SMP Negeri 2 Blora.

Berdasarkan latar belakang tersebut, maka peneliti ingin melakukan penelitian dengan judul "Penanaman Nilai Karakter dan Multikultural dalam Pembelajaran Ilmu Pengetahuan Sosial di SMP Negeri 2 Blora".

Rumusan masalah dalam penelitian ini yaitu (1) Bagaimana cara menanamkan nilai karakter dan multikultural dalam pembelajaran IPS di SMP Negeri 2 Blora?; (2) Bagaimana faktor penunjang untuk menanamkan nilai karakter dan multikultural pada siswa SMP Negeri 2 Blora?.

Landasan teorinya yaitu, Prudance Crandall dalam Elma (2018) mengungkapkan bahwa pendidikan multikultural merupakan pendidikan yang memfokuskan pada latar belakang siswa baik dari aspek ras, keragaman suku (etnis), budaya (kultur) dan agama. Hal ini mengandung pemahaman bahwa perbedaan yang ada bukan menjadi alasan untuk memberikan perlakuan yang berbeda kepada masing-masing peserta didik. Pendiddikan multikultuiral, berasal dari perhatian seorang pakar pendidikan Amerika Serikat Prudence Crandall yang secara intensif menyebarkan pandangan tentang arti penting latar belakang peserta didik, baik ditinjau dari aspek budaya, etnis, dan agama.

Elma (2018) menjelaksan tujuan utama pendidikan multikutural adalah mengubah pendekatan pelajaran dan pembelajaran dengan cara memberikan peluang yang sama pada siswa agar tidak ada yang dikorbankan atas nama persatan. Selain itu tujuan lain pendidikan multikultural adalah untuk membantu siswa memahami latar belakang dari dan kelompok dalam masyarakat, menghirmati dan mngepresiasi kebhinekaan budaya dan sosio historis etnik, menyelesaikan sikap-sipak yang terlalu etnosentris, serta memahami faktor-faktor yang menyebabkan terjadinya polarisai etnik ketimpangan dan ketersaingan.

Rachman dan Lestari dalam Ratna (2019) memebrikan pengertian karakter adalah nilainilai yang khas-baik (tahu nilai kebaikan, mau berbuat baik, nyata berkehidupan baik, dan berdampak baik terhadap lingkungan) yang terpateri dalam diri dan terejawatahkan dalam perilaku.

Pendidikan karakter menurut Ratna Megawangi dalam Koesuma (2012:5) adalah sebuah usaha untuk mendidik anak-anak agar dapat mengambil keputusan dengan bijak dan mengaplikasikan hal tersebut dalam kehidupan sehari-hari, sehingga mereka dapat memberikan sumbangsih yang positif kepada lingkungan sekitarnya. Nilai-nilai karakter yang perlu ditanamkan kepada anak-anak adalah nilai-nilai universal yang mana seluruh agama, tradisi, dan budaya pasti menjunjung tinggi nilai-nilai tersebut.

Kemendikbud (2017) dalam buku Konsep dan Pedoman Pengutaan Pendidikan Karakter menjelasakan Gerakan Penguatan Pendidikan Karakter (PPK) selain merupakan kelanjutan dan kesinambungan dari Gerakan Nasional Pendidikan Karakter Bangsa Tahun 2010 juga merupakan bagian integral Nawacita : Revolusi Karakter Bangsa dan Gerakaan Revolusi Mental dalam pendidikan yang hendak mendorong seluruh pemangku kepentingan untuk mengadakan perubahan paradigma, yaitu perubahan pola pikir dan cara bertindak, dalam mengelola sekolah.

M. Numan Soemantri dalam Wulandari (2013), mengemukakan bahwa Pendidikan IPS adalah suatu pernyederhanaan disiplin ilmuilmu sosial, ideologi negera dan disiplin ilmu 
lainnya serta masalah-masalah sosial terkait, yang diorganisasikan dan disajikan secara ilmiah dan psikologi untuk tujuan pendidikan pada tingkat pendidikan dasar dan menengah.

\section{METODE}

Jenis penelitian ini adalah penelitian kualitatif deskriptif menggunakan pendekatan studi kasus. Latar penelitian di SMP Negeri 2 Blora. Fokus penelitian ini mengenai cara menanamkan nilai karakter dan multikultural dalam pembelajaran IPS dan faktor penunjang untuk menanamkan nilai karakter dan multikultural di SMP Negeri 2 Blora. Sumber data dalam penelitian ini yaitu, data primer berupa hasil wawancara dengan informan dan data sekunder berupa sumber daya manusia di SMP Negeri 2 Blora yang terdiri dari kepala sekolah, guru mata pelajaran IPS dan siswa. Teknik pengumpulan data menggunakan observasi, wawancara dan dokumentasi. Uji validitas data dalam penelitian ini menggunakan triangulasi tekik.

\section{HASIL DAN PEMBAHASAN}

Cara Menanamkan Nilai Karakter dan Multikultural dalam Pembelajaran Ilmu Pengetahuan Sosial di SMP Negeri 2 Blora

Penanaman nilai karakter dan multikultural sangat efektif apabila dilaksanakan pada sekolah yang memang memiliki latar belakang peserta didik yang beragam seperti SMP Negeri 2 Blora, dan pembelajaran ilmu pengetahuan sosial dianggap sebagai mata pelajaran yang sangat penting dan cocok dalam menanamkan nilai karakter dan multikultural kepada peserta didik. Karena, dalam pembelajaran ilmu pengetahuan sosial yang berkaitan dengan penanaman nilai karakter dan multikultural siswa dituntut untuk memiliki pola pikir secara nyata untuk membedakan mana yang bernilai positif dan negatif. Menurut Saidiharjo dalam Sudrajat (2014) menjelaskan pendidikan ilmu pengetahuan sosial adalah program pendidikan yang membina peserta didik agar menjadi warga negara yang baik dalam suasana kedamaian. Indikatornya, setelah peserta didik mempelajarai ilmu pengetahuan sosial, anak memiliki sejumlah kompetensi yaitu berkomunikasi, beradaptasi, bersinergi dengan baik dan selalu berfikir positif terhadap orang lain.

Pembelajaran Ilmu Pengetahuan Sosial berbasis dalam penanaman nilai karakter dan multikultural di SMP Negeri 2 Blora melalui kegiatan perencanaan pembelajaran yang di lakukan oleh guru mapel ilmu pengetahuan sosial yaitu melalui penyusunan dan pengembangan RPP hingga mempersiapkan media dalam pembelajaran yang akan dilaksanakan. Penyusunan RPP yang dilakukan oleh guru ilmu pengetahuan sosial yakni dengan menyeleksi dan menganalisis materi pembelajaran yang mengandung dan dapat dikaitkan dengan proses penanaman nilai karakter dan multikultural. Materi ilmu pengetahuan sosial kelas VII, VIII, dan IX semester genap dapat dikaitkan kedalam proses penanaman nilai karakter dan multikultural kepada peserta didik. Proses penanaman nilai karakter dan multikultural dilakukan dari awal mulai pembelajaran berlangsung hingga pembelajaran diakhiri dengan evaluasi oleh guru ilmu pengetahuan sosial.

Kaitanya dalam kegiatan pembelajaran yang dilakukan oleh guru ilmu pengetahuan sosial melalui kegiatan pembelajaran seperti kerja kelompok, lingkungan sebagai sumber belajar dan pembelajaran ceramah/lisan dengan mengaitkan materi pembelajaran ilmu pengetahuan sosial yang mengandung nilai karakter dan multikultural. Penggunaan media pembelajaran ilmu pengetahuan sosial juga diperhatikan, agar dalam pembelajaran ilmu pengetahuan sosial yang bermuatan nilai karakter dan multikultural lebih menyenangkan dan kreatif, penggunaan media pembelajaran yang digunakan guru ilmu pengetahuan sosial SMPN 2 Blora yaitu power point, video pembelajaran, globe, dan peta besar.

Penggunaan model pembelajaran kelompok dalam penanaman nilai karakter dan multikultral yakni siswa secara langsung dapat berinteraksi dengan temanya yang notambene memiliki keberagaman seperti agama, budaya, dan status sosial mereka, hal ini secara tidak langsung melatih peserta didik dalam menanamkan nilai toleransi kepada temantemanya. Hal ini selaras pendapat dari Slavin dalam Ainun (2016) mengemukakan bahwa belajar kelompok atau kooperatif adalah suatu model pembelajaran yang didalamnya siswa belajar dan bekerja melalui kelompok-kelompok keci; secara kolaboratif yang anggotanya terdiri atas empat sampai enam orang, dengan struktur kelompok heterogen.

Lingkungan sebagai sumber belajar juga digunakan dalam penanaman nilai karakter dan multikultural melalui pembelajaran ilmu pengetahuan sosial, karena dalam materi ilmu pengetahuan sosial sangat kompleks ada dan bersumber dari lingkungan sekitar peserta didik. 
Proses penanaman nilai karakter dan multikultural dengan menggunakan lingkungan sebagai sumber belajar memiliki keuntungan yang diperoleh antara lain: sebagai media sumber belajar, kegiatan belajar lebih menarik, hakikat belajar lebih bermakna, bahan pembelajaran lebih faktual, kegiatan belajar lebih konprehensif, sumber belajar lebih kaya, membentuk pribadi siswa agar tidak asing dengan kehidupan sekitar. Hal ini selaras dengan pendapat Ruswandi dalam Pratiwi Putri (2017) yang menyatakan bahwa : memanfaatkan lingkungan sebagai media pembelajaran akan menjadikan proses belajar mengajar lebih bermakna, karena para siswa dihadapkan langsung pada peristiwa dan keadaan yang sebenarnya secara alami. Sesuatu yang dipelajari oleh siswa menjadi lebih nyata, lebih faktual dan keberadaanya lebih dapat dipertanggung jawabkan.

Sedangkan metode ceramah atau lisan digunakan dalam penanaman nilai karakter dan multikultural dalam pembelajaran ilmu pengetahuan sosial memiliki keunggulan yaitu guru secara langsung menamankan nilai tersebut dengan perilaku atau perkataan yang disampaikan guru dalam materi pembelajaran ilmu pengetahuan sosial yakni guru juga bisa menyelipkan motivasi-motivasi dan pengembangan nilai karakter dan multikultural dalam pembelajaran ilmu pengetahuan sosial berlangsung. Hal ini selaras dengan paradigma mulitkultralisme yang di sampaikan oleh Sitaresmi dalam Yaya Suryana (2015) sebagai berikut: 1) menyampaikan pesan tentang multikulturalisme dengan memberikan tontoh kehidupan sehari-hari, dan 2) secara tidak langsung, yaitu dengan penyampaikan cerita yang berisi pesan tentang multikulturalisme, anatara lain dari dongeng, lengenda, dan fabel.

Keberagaman dalam siswa SMP Negeri 2 Blora dari sisi agama, budaya dan satus sosial. Hal ini yang menjadikan perlunya penanaman nilai dari pendidikan multikultural di sekolah, dalam kaitanya dengan pendidikan multikultural menurut Prudance Crandall dalam Elma (2018) menjelaskan bahwa pendidikan multikultural merupakan pendidikan yang memfokuskan pada latar belakang siswa baik dari aspek ras, keragaman suku (etnis), budaya (kultur) dan agama. Nilai multikultural yang diterapkan di SMP Negeri 2 Blora khusunya dalam pembelajaran ilmu pengetahuan sosial mencakup semua nilai multikultural yang ada pada visi dan misi SMPN 2 Blora. Menurut Yaya Suryana dalam Elma (2018) menjelaskan nilai yang harus diperhatikan dalam penanaman nilai pendidikan multikultural, yaitu antara lain:

\section{a. Nilai Toleransi}

Sikap menghormati, menerima pilihan, pandangan, keyakinan, kebiasaan, dan pendapat orang lain yang berbeda dengan dirinya. Nilai toleransi terlihat dalam pembelajaran ilmu pengetahuan sosial dengan keharmonisan antara guru dan siswa yang memiliki perbedaan agama, budaya, dan status sosial. Perilaku siswa dalam satu kelas yang memiliki perbedaan diantranya akan tetapi mereka tidak memperdulikan dengan adanya perbedaan itu, mereka saling berteman dan belajar bersama tanpa membeda-bedakan agama, budaya, dan status sosial mereka.

\section{b. Nilai Kesamaan/Kesetaraan}

Mengakui adanya persamaan derajat persamaan hak, dan persamaan kewajiban sebagai sesama manusia. Dalam proses pendidikan seharusnya pendidikan menganggap sesama peserta didik itu sama tidak menspesialkan atau membedakan antara peserta didik yang satu dengan peserta didik yang lain. Nilai kesamaan dan kesetaraan terlihat dalam memberikan kesempatan kepada peserta didik untuk memberikan pendapat dan argument dalam pembelajaran.

\section{c. Nilai Kekerabatan/ Persaudaraan}

Sikap bersahabat, kekeluargaan yang lahir dari rasa persaudaraan dan menjadi bagian dari kelompok dan masyarakat itu sendiri. Dengan adanya rasa kekeluargaan ini akan muncul rasa kesetiakawanan, rasa persaudaraan dengan berbagai suku bangsa, etnis, golongan dan agama, serta memahami akan arti perbedaan. Nilai kekerabatan dan persaudaraan terlihat dengan jarang terjadi sebuah konflik atau permasalahan antar siswa yang didasari oleh perbedaan mereka.

\section{d. Nilai Persatuan}

Membentuk pemahaman, pikiran dan sikap yang mengutamakan keutuhan dan kedaulatan, kebersamaan dan kerjasama. Nilai persatuan terlihat yakni siswa menghormati dan menghargai bapak/ibu guru dalam penyampaian materi dan pendapat temanya dalam diskusi bersama serta gotong-royong dalam kegiatan kelas.

\section{e. Nilai Keadilan}

Memberikan hak kepada seorang sesuai dengan porsinya masing-masing. Sehingga adanya keseimbangan dan keharmonisan antara menuntut hak dengan menjalankan kewajiban, mengakui adanya potensi yang sama dalam berekspresi, dan mengakui adanya kesempatan yang sama dalam pelayanan publik. Nilai keadilan terlihat pada guru yang memberikan 
hak penuh kepada siswa untuk belajar di sekolah seperti menjelaskan lagi materi yang sekiranya kurang dipahami oleh beberapa siswa siswa dengan metode yang lebih mudah dipahami oleh siswa yang kurang memahami isi materi diajarkan.

Penanaman nilai multikultural di SMP Negeri 2 Blora secara tidak langsung juga membentuk karakter siswa melalui pendidikan karakter yang talah diterapkan di sekolah dalam program Gerakan Penguatan Pendidikan Karakter (PPK) yang merupakan Gerakan Nasional Pendidikan Karakter Bangsa Tahun 2010 juga merupakan integrasi Nawacita : Revolusi Karakter Bangsa dan Gerakan Revolusi Mental. Penanaman nilai karakter sangatlah penting dilakukan di sekolah, karena penanaman karakter tertuang dalam tujuan pendidikan nasional yaitu untuk mengembangkan potensi peserta didik untuk memiliki kecerdasan, kepribadian dan akhlak.

Nilai pendidikan karakter yang diterapkan di SMP Negeri 2 Blora yaitu pengintregasian program Gerakan Penguatan Pendidikan Karakter yang disampaikan oleh Kemendikbud melalui buku konsep dan pedoman penguatan pendidikan karakter, yang mana memberikan 5 rumusan nilai utama karakter bangsa yang data diprioritaskan dalam pelaksanaan program penguatan pendidikan karakter (Kemendikbud, 2017), yaitu :

\section{f. Religius}

Nilai karakter religius ini meliputi tiga dimensi relasi sekaligus, yaitu hubungan individu dengan Tuhan, individu dengan sesama, dan individu dengan alam semesta (lingkungan). Nilai religius juga tercantum dalam visi dan misi SMPN 2 Blora yang dimana menjadi pedoman untuk proses penanaman nilai karakter dan multikultural di dalam lingkungan sekolah. Nilai religius dalam penanaman nilai karakter melalui pembelajaran ilmu pengetahuan sosial tampak pada awal pembelajaran dengan membaca doa yang dianutnya sebagai bentuk toleran terhadap pelaksaanaan ibadah agama lain. Para siswa juga menghargai dengan adanya perbedaan di antara meraka, hal ini tampak dengan adanya sikap toleransi pada siswa lainnya dan menciptakan suasana belajar yang menyenangkan.

\section{g. Nasionalis}

Nilai nasionalis tampak pada awal pembelajaran berlangung siswa diwajibkan untuk menyanyikan lagu kebangsaan dan di setiap hari jumat menyanyikan lagu daerah hal ini menunjukkan agar siswa memiliki jiwa cinta tanah air dan memiliki daya juang yang tinggi. Mengaitkan materi yang ada di dalam pembelajaran seperti materi di kelas 8 tentang perubahan masyarakat indonesia pada masa penjajahan dan tumbuhnya semngat kebangsaan dan pada materi kelas 9 tentang Indonesia dari masa kemerdekaan hingga masa reformasi, hal ini memberikan arahan kepada siswa agar memiliki jiwa nasionaslis dan cinta tanah air.

\section{h. Mandiri}

Nilai mandiri terlihat dalam ujian atau tes yang mengharuskan siswa harus megerjakan sendiri tanpa harus mencontek, secara tidak langung juga melatih siswa memiliki sifat kejujuran. Pemberian tugas seperti membuat peta, powerpoint atau tugas yang melatih siswa dalam kreatifitas.

\section{i. Gotong-royong}

Nilai gotong royong terlihat dengan adanya kerja sama di dalam setiap kelompok, meraka harus membagi tugas kepada temanteman agar tugas kelompok tersebut segera terselesaikan.

\section{j. Integritas}

Nilai Integritas terlihat dalam mengerjakan tugas dari bapak/ibu guru tepat waktu, tidak mencontek saat ulangan ataupun ujian yang diberikan, agar memiliki sikap tanggung jawab dari diri siswa dan menghargai guru serta warga sekolah lainnya.

Evaluasi pembelajaran ilmu pengetahuan sosial delam penanaman nilai karekter dan multikultural pada siswa SMP Negeri 2 Blora sudah terintegrasikan pada Rencana Pelaksanaan Pembelajaran (RPP). Evaluasi kepada peserta didik dapat terlihat dari seluruh aspek kognitif dengan membuat dan mengerjakan soal, serta dalam ranah afektif bisa dilihat dari sikap peserta didik yang selanjutnya dimasukkan dalam rapor yang berbentuk narasi (K-13). Ranah psikopotorik dilihat dari ujuan kompetensi dari peserta didik. Evaluasi atau penilaian pada ranah afektif, kognitif dan psikomotorik selalu mengacu pada aturan perangkat pembelajaran yang sudah ditetapkan. Menurut Print dan Lange dalam Maszid (2019) mengemukakan bahwa berbagai macam bentuk evaluasi yaitu dengan banyak model, sampel sekolah tidak cukup untuk dapat memberikan analisis yang kuat keberhasilan mereka.

Faktor Penunjang untuk Menanamkan Nilai Karakter dan Multikultural pada Siswa SMP Negeri 2 Blora.

Faktor penunjang sangatlah penting dalam pelaksanaan pembelajaran, selain dapat membantu dan menopang serta memfasilitasi 
pembelajaran, faktor dapat digunakan dalam kelancaran serta keberhasilan dalam penanaman nilai karakter dan multikultural di sekolah.

Kaitanya dengan faktor penunjang dalam penanaman nilai krakter dan multikultural disekolah peran kepala sekolah dan guru menjadi yang terpenting dalam proses penanaman, karena merekalah sosok agen sosialisai, fasilitator dan motivasi secara langsung kepada peserta didik. Menurut Rutherford dan Seirgiovanni dalam Jahiriansayah menyatakan bahwa kepala sekolah yang efektif adalah kepala sekolah yang dapat memberdayakan sumber-sumber yang ada di sekolah dan lingkunganya secara efektif. Satu diantara sumber utama yang harus diberdayakan adalah guru, karena guru merupakan faktor penetu keberhasilan di hampir semua program sekolah. Jadi, dari penjelasan tersebut guru juga memiliki faktor penting dalam kesuksesan penanaman nilai karakter dan multikultural di sekolah.

Guru memiliki tugas sebagai pendidik dan pengajar, pendidik dikaitkan dalam mengajarkan atau menumbuhkan karakter baik kepada peserta didik, sedangkan pengajar yaitu guru harus bisa mentranfer ilmu kepada peserta didik. Kompetensi guru juga menjadi faktor pentinng, karena kompetensi guru merupakan seperangkat penguasaan kemampuan yang harus ada dalam diri guru agar dapat mewujudkan kinerjanya secara tepat dan efektif. Kaitanya peran guru dalam proses pembelajaran, Gage dan Berliner dalam Kirom (2017) melihat ada tiga fungsi utama guru dalam pembelajaran, yaitu sebagai perencana (planner), pelaksanaan dan pengelola (organizer) dan penilai (evaluator).

Penggunaan kurikulum di SMP Negeri 2 Blora menggunakan kurikulum 2013 yang memiliki tujuan mengubah sikap pembelajara agar lebih santun melalui nilai-nilai pendidikan karakter yang terkandung didalamnya. Artinya jika memiliki sikap dan mental yang terpuji maka pembelajaran akan mampu menyerap ilmu dengan baik dan tentu menjadi generasi yang bersih. Penggunakan media pembelajaran juga sangat penting dalam penanaman nilai karakter dan multikultural di dalam kelas, penggunan media pembelajaran menjadikan pembelajaran lebih menarik dan di minati oleh siswa. Media pembelajaran di SMP Negeri 2 Blora sangat lengkap dalam menunjang proses pembelajaran seperti LCD, papan tulis, leptop serta alat peraga yang ada di laboratorium sekolah.
Program sekolah juga dapat menjadi faktor penunjang dalam penanaman nilai karakter dan multikultural di sekolah yaitu program sekolah Adiwiyata dan program Gerakan PPK yang dilaksanakan di SMP Negeri 2 Blora. Menurut Chaeruddin dalam Silaban (2017) menyebutkan bahwa pelaksanaan program Adiwiyata diletakkan pada dua prinsip sebagai berikut: 1) Partisipatif, seluruh komponen sekolah harus terlibat dalam keseluruhan proses yang meliputi perencanaan, pelaksanaan dan evaluasi tanggung jawab dan perannya masing-masing, 2) Berkelanjutan (sustainable) seluruh kegiatan harus dilakukan secara terencana dan terus menerus secara komprehensif. SMP Negeri 2 Blora merupakan penerima penghargaan adiwiyata tingkat SMP di Kabupaten Blora, hal ini didukung dengan tingkat kepedulian yang tinggi dan juga partisipatif dari seluruh warga sekolah dalam menjaga lingkungan, hal inilah yang menjadi program sekolah yang didalamnya dapat dijadikan sebagai faktor dalam penanaman nilai karakter dan multikultural yakni nilai gotongroyong dan toleransi.

Program lain yang dapat menanamkan nilai karakter dan multikultural di SMP Negeri 2 Blora yakni dengan adanya program Gerakan Penguatan Pendidikan Karakter (PPK), karena dalam program inilah SMP Negeri 2 Blora mengambil nilai yang terkandung dalam program Gerakan PPK ini, nilai tersebut yakni religious, nasional, mandiri, gotong-royong, dan integeritas. Nilai PPK ini ditanamkan kepada peserta didik melalui pembelajaran di kelas dan dilingkungan sekolah.

Asmani dalam Lestari (2016) ekstrakulikuler selama ini dipandang sebalah mata, hanya sebagai pelengkap kegiatan intrakulikuler. Hal ini sangat disayangkan sekali, karena menurut Karim dalam Lestari (2016) melalui ekstrakulikuler peserta didik diarahkan memiliki karakter yang abadi dan universal seperti kejujuran, kedisiplinan, menghargai pluralism, mempunyai empati dan simpati. Semua aspek ini terkandung dalam nilai karakter dan multikultural yang nantinya akan sangat menunjang kesuksesan peserta didik kelak di masa mendatang. Ektrakulikuler di SMP Negeri 2 Blora memberikan pengembangan bakat dan minat peserta didik, dan secara tidak langsung kegiatan ekstrakulikuler di sekolah juga dapat menanamkan nilai karakter dan multikultural, sebagai contoh kegiatan pramuka yang didalam kegiatan tersebut peserta didik dituntut untuk memiliki jiwa solidaritas antar teman. 
Fasilitas sekolah sangat penting dalam menunjang pelaksanaan pembelajaran di sekolah, terutama dalam penanaman nilai karakter dan multikultural di SMP Negeri 2 Blora. Fasilitas di SMP Negeri 2 Blora sangatlah lengkap dalam menujang pembelajaran, dan fasilitas sekolah secara tidak langsung digunakan oleh guru dalam penanaman nilai karakter dan multikultural kepada peserta didik, fasilitas tersebut antara lain yaitu ruang kelas, ruang kelas sendiri adalah fasilitas terpenting dalam penanaman nilai karakter dan multikultural, karena di dalam raung kelas peserta didik dan guru bisa bertemu secara langsung dalam kegiatan pembelajaran yang berbasis penanaman nilai karakter dan multikultural.

Fasilitas lainya adalah tempat ibadah yang ada di SMP Negeri 2 Blora, tempat ibadah yang ada yaitu masjid dan gereja, kedua tempat ibadah ini selain dugunakan untuk tempat ibadah warga sekolah juga digunakan untuk tempat pembelajaran agama yang mengajak siswa untuk belajar langsung di tempat ibadah. Sebagai contoh di masjid digunakan untuk praktek membaca Al-Quran dan praktek sholat. Adanya fasilitas kantin kejujuran di SMP Negeri 2 Blora juga memberikan pelajaran kepada peserta didik dalam pembentukan karakter yaitu nilai kejujuran yang sejak dini harus diterapkan dalam diri peserta didik.

Fasilitas pendukung lainnya yaitu laboratorium dan perpustakaan sekolah. Laboratorium yang ada di SMP Negeri 2 Blora sendiri sangat lengkap dalam menunjang pembelajaran, laboratorium tersebut antaralain labolatorium IPA, Bahasa, Musik, dan Komputer. Penggunaan laboratorium sebagai tempat belajar memberikan hal positif bagi siswa antara lain sebagai tempat untuk berlatih mengembangkan keterampilan intelktual melalui kegiatan pengamatan, pencatatan, dan mengkaji gejala-gejala lain, dan memberikan rasa percaya diri sebagai akibat keterampilan dan pengetahuan atau penemuan yang diperoleh dalam pelajaran tertentu. Pembelajara yang dilakukan di labolatorium, siswa juga dapat menerima penanaman nilai karakter dan multikultural dari guru secara langsung dengan pembentukan kelompok-kelompok kecil dalam pembelajaran berlangsung.

\section{SIMPULAN}

Pembelajaran ilmu pengetahuan sosial dapat menanamkan nilai karakter dan multikultural melalui pembelajaran secara berkelompok dan lisan serta memanfaatkan lingkungan sebagai sumber belajar. Nilai karakter yang ditanamkan berpedoman langsung dengan Gerakan Penguatan Pendidikan Karakter dan Nilai multikultural yang ditanamkan berpedoman langsung pada nilai toleran, kesamaan/ kesetaraan, kekerabatan/ persaudaraan, persatuan dan keadilan. Evaluasi pembelajaran ilmu pengetahuan sosial yang bermuatan nilai karakter dan multikultural dapat terlihat dari seluruh aspek dalam pembelajaran.

Faktor penunjang dalam menanamkan nilai karakter dan multikultural meliputi peran kepala sekolah dan guru sebagai sosok agen sosialisai, fasilitator dan motivasi, kurikulum sekolah, program-program sekolah, fasilitas sekolah dan beberapa kegiatan rutin yang ada di sekolah.

\section{DAFTAR PUSTAKA}

Ainun Lubis, Nur dan Hasrul Harahap. 2016. Pembelajaran Kooperatif Tipe Jigsaw. Jurnal As-Salam. Vol.1, No. 1, MeiAgustus 2016.

Elma Kumala, Aziza.2018.Penanaman NilaiNilai Multikultural Dalam Pembelajaran Pendidikan Agama Islam Di SMP Negeri 1 Mertoyudan Kabupaten magelang. Skripsi. Yogyakarta: Universitas Islam Indonesia.

Kemendikbud. 2017. Konsep dan Pedoman Penguatan Pendidikan Karakter. Jakarta : Kementrian Pendidikan dan Kebudayaan.

Kesuma, Dharma, Triatna, Johar Permana. 2012. Pendidikan Karakter (Kajian Teori dan Praktik di Sekolah. Bandung. Remaja Rosdakrya.

Kirom, Askhabul. 2017. Peran Guru dan Peserta Didik Dalam Proses Pembelajaran Berbasis Multikulural. Al-Murabbi : Jurnal Pendidikan Agama Islam. Volume 3, Nomor 1, Desember 2017.

Lestari, Ria Yuni. 2016. Peran Kegiatan Ektrakulikuler dalam Mengembangkan Watak Kewarganegaraan Peserta Didik. Untirta Civic Education Jurnal. Vol. 1, No. 2, desember 2016.

Mazid, Sukron, Suharno Suharno. 2019. Implementasi Nilai-Nilai Multikultural dalam Pembelajaran Pendidikan Kewarganegaraan. Harmoni Sosial : Jurnal Pendidikan IPS. Volume 6, No 1, Maret 2019.

Pratiwi Putri, Rayssa, Suid AB, dan Nasir Yusuf. 2017. Kemampuan Guru Memanfaatkan Lingkungan SebagaiSumber Belajar Di 
Sekolah Dasar Negeri 29 Banda Aceh. Jurnal Ilmiah Pendidikan Guru Sekolah Dasar. FKIP Unsiyah Volume 2, Nomer 2, 84-91, Ampirl 2017.

Ratna Ratih, Linda. 2019. Penguatan Pendidikan Karakter Cinta Tanah Air Melalui Ekstrakurikuler Musik Keroncong Di SMA Negeri Purworejo. Skripsi. Semarang: Universitas Negeri Semarang.

Sudrajat. 2014. Pendidikan Multikultural Untuk Meningkatkan Kualitas Pembelajaran IPS di Sekolah Dasar. Jurnal JIPSINDO. No1, Volume 1, Maret 2014.

Sudrajat. 2014. Revitalisasi Pendidikan Multikultural Dalam Pembelajaran. Jurnal Pembangunan Pendidikan : Fondasi dan Aplikasi. Volume 2, Nomer 1. 2014.
Suryana, Yaya dan Rusdiana. 2015. Pendidikan Multikultural Suatu upaya Penguatan Jati Diri Bangsa Konsep-Prinsi-Implementasi. Pustaka Setia.

Omeri, Nopan.2015. Pentingnya Pendidikan Karakter Dalam Dunia Pendidikan. Jurnal Manajer Pendidikan. Volume 9, Nomer 3. Juli 2015, hlm 464-468.

Wulandari, Isti. 2013. Upaya Meningkatkan Aktifitas Siswa Dalam Pembelajaran IPS Melalui Metode Active Learning Tipe True Or False ( Benar Atau Salah) Kelas VII C Di SMP N 4 Wonosari. Skripsi. Yogyakarta: Universitas Negero Yogyakarta.

Zubaedi. 2011. Desain Pendidikan Karakter. Jakarta: Kencana Prenada Media Group 